\title{
Pendidikan Kesehatan Dalam Pencegahan Seks Pranikah Pada Remaja di SMK Migas Teknologi Riau
}

\author{
Fatma Nadia' ${ }^{1}$ Lisviarose $^{2}$, Rika Ruspita ${ }^{3}$ \\ 1,2,3Program Studi Kebidanan Program Sarjana Terapan, STIKes Al Insyirah Pekanbaru \\ *e-mail: fatmanadia40@gmail.com¹, lisviarose@gmail.com ${ }^{2}{ }_{2}$ rikaruspita@yahoo.co.id $^{3}$
}

\begin{abstract}
Adolescence is a time of mental emotional change towards adulthood. The problem faced by adolescents today is the increasing free sex behavior. Sexual behavior of adolescents having sexual intercourse in Riau Province 44.23\% in 2012, AIDS aged 20-24 years 16.6\% in 2016 and has increased every year. The cause of the lack of understanding of pre-marital sexuality education obtained by adolescents. SMK Migas Teknologi Riau secondary vocational high school which is dominated by male. Sexual education is not evenly distributed in school, only obtained from social media and peers, thus giving rise to a different paradigm in the eyes of adolescents who are easily influenced by juvenile delinquency, especially sexual behavior. The solution in preventing premarital sex is by providing proper sexual education to adolescents. Extension activities were carried out on Friday, February 28, 2020 in the Hall with 32 students. The method used is the lecture and question and answer method, as well as video playback using Infocus media. Students enthusiastically ask questions and listen to the delivery of the material.
\end{abstract}

Keywords: Sexual education, Adolescence

\begin{abstract}
Abstrak
Remaja merupakan masa perubahan mental emosional menuju dewasa. Permasalahan yang dihadapi remaja saat ini adalah perilaku seks bebas yang semakin meningkat. Perilaku seksual remaja melakukan hubungan seksual di Provinsi Riau 44,23\% tahun 2012, AIDS umur 20-24 tahun 16,6\% tahun 2016 dan mengalami peningkatan setiap tahun. Penyebab kurangnya pemahaman terhadap pendidikan seksualitas pra nikah yang didapat oleh remaja. SMK Migas Teknologi Riau menengah Sekolah Menengah Kejuruan yang didominasi oleh laki-laki. Pendidikan Seksual tidak merata dibangku sekolah, hanya didapatkan dari media sosial dan teman sebaya, sehingga memunculkan paradigma berbeda dimata remaja yang mudah terpengaruh pada kenakalan remaja terutama perilaku seksual. Solusi dalam pencegahan seks pranikah dengan memberikan penyuluhan pendidikan seksual yang benar terhadap remaja. Kegiatan penyuluhan dilakukan pada hari Jum'at, 28 Februari 2020 di Aula dengan jumlah peserta 32 siswa. Metode yang digunakan adalah metode ceramah dan tanya jawab, serta pemutaran Video menggunakan media Infokus. Siswa antusias bertanya dan mendengarkan penyampaian materi.
\end{abstract}

Kata kunci: Pendidkan seksual, remaja

\section{PENDAHULUAN}

Remaja merupakan harapan bangsa yang akan menentukan kehidupan bangsa dimasa yang akan datang. Sebagai generasi harapan bangsa, remaja memiliki konsep diri yang positif untuk memahami dan mengenal dirinya, karena remaja merupakan perhatian khusus bagi masyarakat dan pemerintah. (Kemenkes RI, 2014).

Batasan usia remaja menurut WHO (badan PBB untuk kesehatan dunia) adalah 12 sampai 24 tahun. Pada masa ini terjadi perkembangan yang dinamakan masa Puberitas. Remaja memiliki sejumlah keinginan dan tuntutan psikologi yang muncul dan diinginkan. Perlu sekali arahan orangtua, guru dan teman sebaya. (Dale \& Dale, 2019). Salah satu dampak buruk dari perilaku remaja adalah perilaku seks bebas yang mengakibatkan remaja Indonesia terganggu kesempatannya untuk melanjutkan sekolah, memasuki dunia kerja, memulai berkeluarga, dan menjadi anggota masyarakat secara baik. (Imron, 2012).

Perilaku seksual remaja merupakan segala bentuk tingkah laku yang didorong oleh hasrat seksual baik dengan lawan jenis maupun sesama jenis. Remaja usia 15 - 24 tahun yang melakukan hubungan seksual sebanyak 66, 55\% secara Global, 2,2 \% di Malaysia, 45\% di Provinsi Riau dan 
44, $23 \%$ di Pekanbaru. Salah satu faktor yang berhubungan dengan tindakan perilaku seksual remaja adalah kurangnya pengawasan orang tua, mitos tentang seks yang salah dan gaya hidup modern. .(Marlina et al., 2013)

Penelitian (Setyadani, 2013) dari 15 responden diketahui alasan remaja melakukan hubungan seksual disebabkan karena nafsu yang timbul ketika sedang bersama pasangan, pengalaman melihat orang yang melakukan hubungan seks, suka sama suka, dan ikut-ikutan teman. Selain itu kemajuan teknologi memunculkan banyak persoalan terutama mudahnya akses untuk terpapar pornograpi pada kalangan remaja. (Radjagukguk \& Sriwartini, 2020) Hasil Penelitian (Yutifa et al., 2015) juga menunjukkan bahwa keterpaparan pornografi berpengaruh terhadap perilaku seksual remaja.

Meningkatnya kasus perilaku seksual dikalangan remaja, maka sangat perlunya pemahaman dengan pendidikan seksual pranikah untuk mencegah perilaku seksual berisiko. Salah satu pendidikan kesehatan yang ingin diberikan kepada remaja yaitu pemahaman tentang perilaku seks bebas, dampak dan risiko seks bebas, faktor penyebab seks bebas, serta kesehatan reproduksi pada remaja. Salah satu caranya dengan memberikan penyuluhan kesehatan.

Penyuluhan kesehatan merupakan kegiatan penambahan pengetahuan yang diperutukkan bagi masyarakat melalui penyebaran pesan. (Maulana, 2020). Pemberian penyuluhan kepada remaja sangat perlu dilakukan agar munculnya persepsi yang benar tentang perilaku seksual. Apabila salah pemahaman dapat berpengaruh pada perilaku yang negatif pada remaja.

SMK Migas Teknologi Riau terletak di Kelurahan Simpang Tiga, Kecamatan Bukit Raya Kota Pekanbaru merupakan SMK yang tidak jauh dari STIKes Al-Insyirah Pekanbaru. Hasil wawancara dengan siswa disana, mereka belum pernah mendapatkan penyuluhan tentang seks pra nikah sebelumnya. Dilihat dari aspek administrasi dan kesadaran remaja terhadap kesehatan reproduksi SMK Pekanbaru termasuk Sekolah Menengah Kejuruan yang cukup rawan pada remaja karena berada di kota yang mudah terpapar akses media sosial dan juga pergaulan dengan mayoritas siswanya laki-laki.

\section{METODE}

Metode pendekatan yang dilakukan adalah dengan melakukan pendekatan kepada guru untuk bisa berperan serta mengajak siswa mengikuti penyuluhan tentang pendidikan kesehatan seks pranikah. Kegiatan pengabdian masyarakat ini menggunakan metode pelaksanaan kegiatan penyuluhan yang diterapkan seperti metoda ceramah dan tanya jawab yang dipilih menyesuaikan kriteria sasaran, sumberdaya yang tersedia, tempat dan waktu.

Pertama, melakukan pendekatan kepada guru dan siswa SMK Migas Teknologi Riau. Mendiskusikan tentang pendidikan seksual selama ini yang diterima siswa. Kedua, mempersiapkan materi yang dibuat dalam bentuk Power point (PPT) dan video yang berkaitan dengan materi. Ketiga, mengumpulkan siswa di ruangan untuk memberikan materi dibantu dengan media Infokus dan Pembesar Suara / Microphone. Pelaksanaan kegiatan dilakukan pada hari Jum'at tanggal 28 Februari 2020 di SMK Migas Teknologi Riau di Jl. Srikandi, RT 04, RW 01 Parit Indah, Kelurahan Simpang Tiga, Kecamatan Bukit Raya, Kota Pekanbaru.

Jumlah peserta yang mengikuti pendidikan kesehatan dalam bentuk penyuluhan berjumlah 32 siswa. Kegiatan ini melibatkan beberapa mahasiswa yang membantu dalam pelaksanaan kegiatan. Evaluasi dilakukan dengan metode tanya jawab secara langsung kepada siswa yang belum memahami materi penyuluhan. 


\section{HASIL DAN PEMBAHASAN}

Pengabdian masyarakat dilaksanakan pada hari Jum'at tanggal 28 Februari 2020. Tempat Pelaksanaan pengabdian Masyarakat di SMK Migas Teknologi Riau Kota Pekanbaru, tepatnya di Jl. Srikandi, RT 04, RW 01- Parit Indah Kelurahan Simpang Tiga, Kecamatan Bukit Raya Kota Pekanbaru. Jumlah peserta yang hadir berjumlah 32 Siswa. Penyuluhan menggunakan infokus dan pemutaran video tentang Seks bebas.

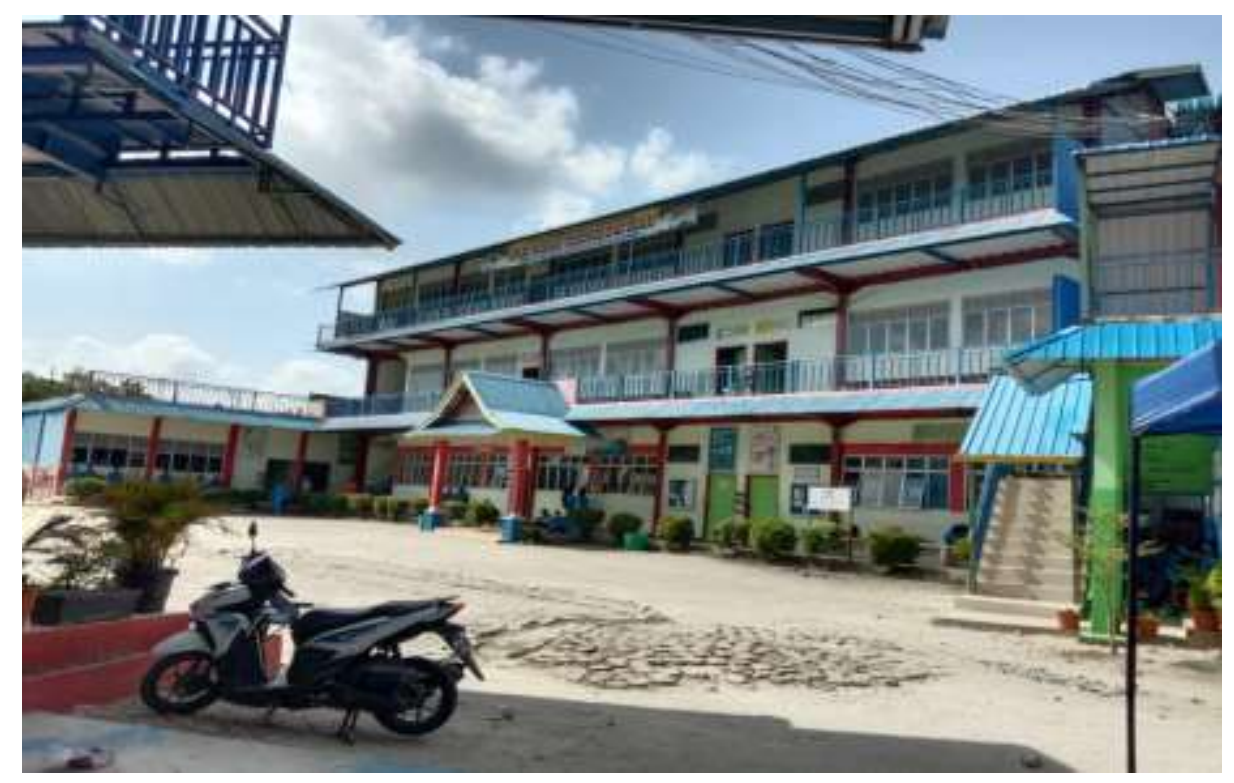

Gambar 1. Lokasi Pengabdian Masyarakat

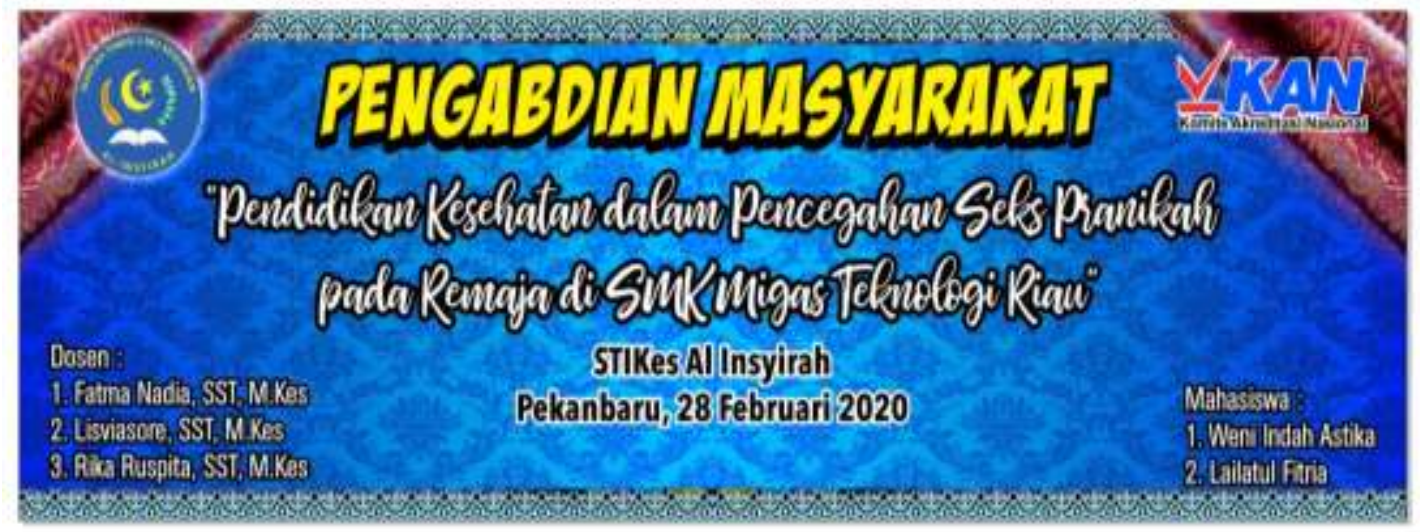

Gambar 2. Spanduk Pengabdian Masyarakat

Adapun tahap pelaksanaan kegiatan pengabdian masyarakat : a. Pengisisan daftar peserta, b. Pembukaan, c. Penyampaian materi pendidikan kesehatan dengan menggunakan LCD (power point) dan pemutaran video, d. Diskusi / tanya jawab dan penutupan. 


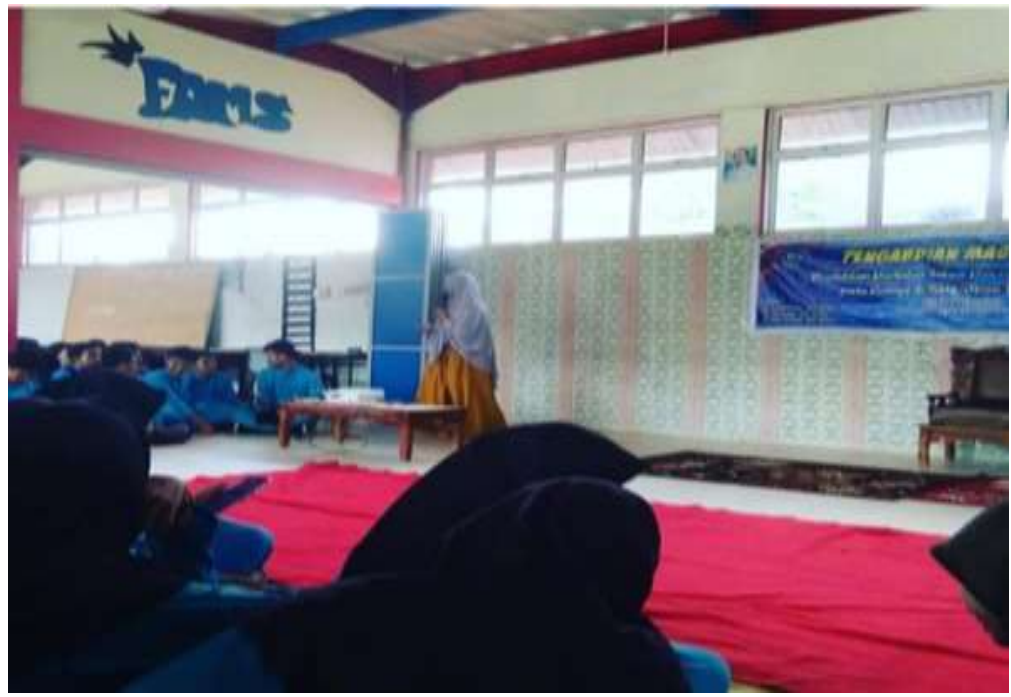

Gambar 3. Sambutan Ketua Pelaksana

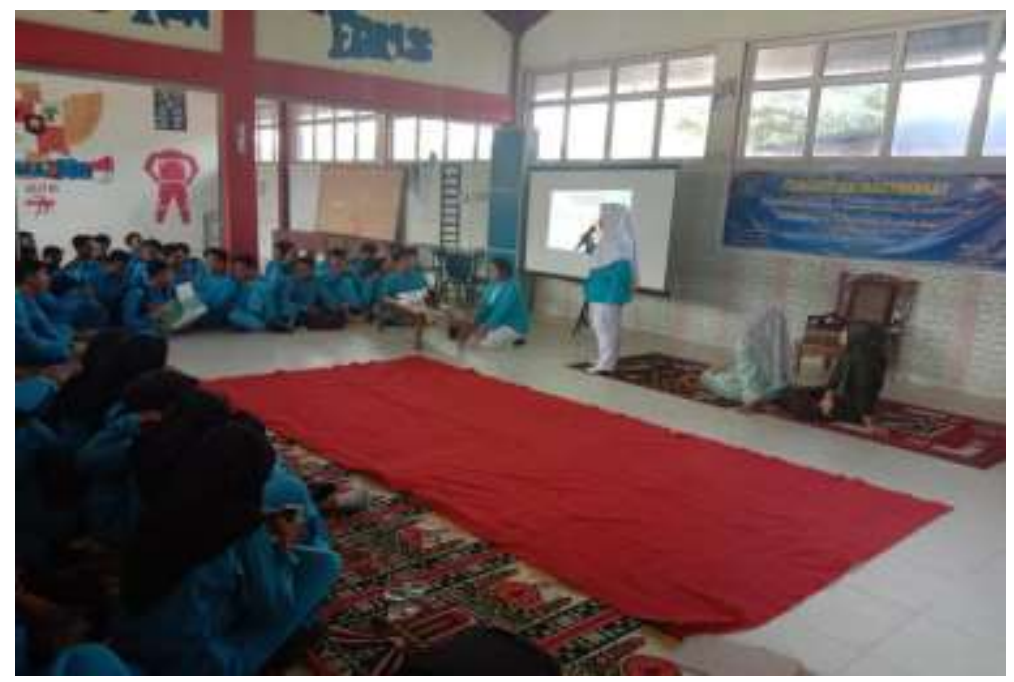

Gambar 4. Penyampaian Materi Penyuluhan

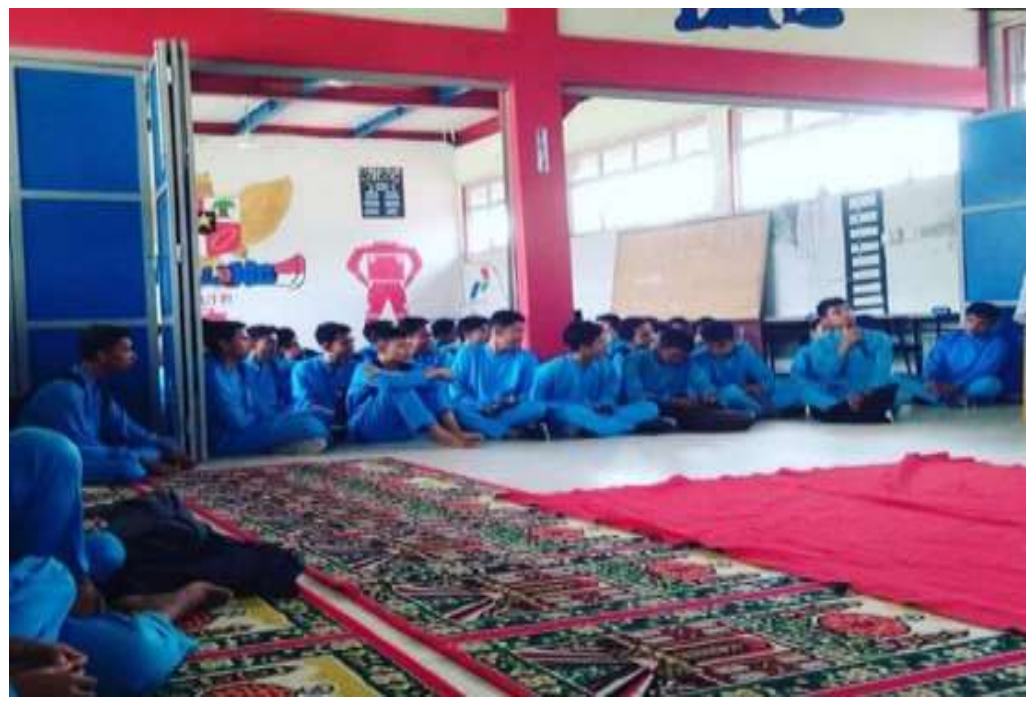

Gambar 5. Peserta bertanya tentang materi 
Peserta pengabdian masyarakat terbagi dari beberapa jurusan. Mereka antusias dalam mendengarkan materi penyuluhan tentang seks pranikah. Materi ini membuat mereka memahami tentang bahaya seks bebas. Mudahnya akses internet, bahkan di manasaja, membuat salah pengertian dan persepsi tentang Seks Pranikah. Salah satu langkah untuk mengetahui pemahaman tentang materi dengan tanya jawab kepada peserta tentang materi.

Perilaku seks bebas pada remaja adalah cara remaja mengeksprestasikan dan melepaskan dorongan seksual, yang berasal dari kematangan organ seksual dan perubahan hormonal dalam berbagai bentuk tingkah laku seksual, seperti berkencan intim, bercumbu sampai melakukan kontak seksual. Pada masa remaja, informasi tentang masalah seksual sudah seharusnya mulai diberikan supaya remaja tidak mendapatkan informasi yang salah dari sumber-sumber yang tidak jelas. (Hamka et al., 2015)

Seks pranikah adalah hubungan seksual yang dilakukan remaja tanpa adanya ikatan pernikahan. Sedangkan perilaku seksual pranikah merupakan perilaku seksual yang dilakukan tanpa melalui proses pernikahan yang resmi menurut hukum maupun agama dan kepercayaan masing-masing. (Sarwono, 2013)

Adapun faktor-faktor yang menyebabkan perilaku seksual pada remaja menurut (Sarwono, 2013), diantaranya adalah :

a. Perubahan-perubahan hormonal yang mengingat hasrat seksual remaja.

b. Penudaan usia perwakilan

c. Adanya tabu atau larangan dalam masyarakat untuk melakukan perilaku seksual sebelum menikah.

d. Kurangnya informasi yang didapat remaja tentang seksualitas dan hal-hal terkait didalamnya.

e. Pergaulan bebas.

Pengetahuan remaja tentang seks bebas masih sangat kurang. Faktor ini ditambah dengan informasi yang keliru yang mereka peroleh dari berbagai sumber yang salah, seperti mitos seputar seks, SCD porno, situs porno di Internet, dan lainnya akan membuat pemahaman dan persepsi anak tentang seks menjadi salah. Pendidikan seksualitas secara luas meliputi berbagai aspek yang berkaitan dengan seks, diantaranya aspek biologis, orientasi, nilai sosiokultur dan moral serta perilaku. (Hamka et al., 2015)

Berdasarkan hasil penelitian (Yutifa et al., 2015) paparan pornografi berpengaruh terhadap perilaku seksual remaja. Responden dengan perilaku seksual tidak berisiko lebih banyak menggunakan frekuensi keterpaparan jarang dan sebaliknya yang berisiko lebih banyak menggunakan frekuensi keterpaparan sering. Perlunya pihak sekolah dan orangtua dalam memperhatikan kegiatan remaja seperti pengawasan dan pembatasan penggunaan handphone maupun media elektronik lainnya yang memberikan kepada remaja.

Selain itu berdasarkan penelitian (Marlina et al., 2013), pengawasan orangtua yang kurang, mitos seks yang salah serta jenis kelamin yang dapat mempengaruhi perilaku remaja SMA se-Kota Pekanbaru. Hasil penelitian (Rokhmah, 2015) Perilaku seksual pada waria sangat berisiko akan penularan HIV/AIDS. Tingkat religiusitas, pengetahuan yang kurang, sikap terhadap seksualitas, akses dan kontak dengan media informasi, sikap teman dekat serta perilaku seksual pranikah teman dekat juga berpengaruh terhadap perilaku seksualitas pada remaja. (Azinar, 2013).

Setelah mengetahui banyak penyebab yang mempengaruhi perilaku seksual pada remaja, maka dampak bahaya dari seks pranikah itu sendiri antara lain :
a. Kehamilan yang tidak diinginkan
b. Aborsi yang tidak aman
c. Dampak psikologi dalam pandangan masyarakat, aib keluarga, mencoret nama baik keluarga.
d. Penyakit Infeksi Menular Seksual 


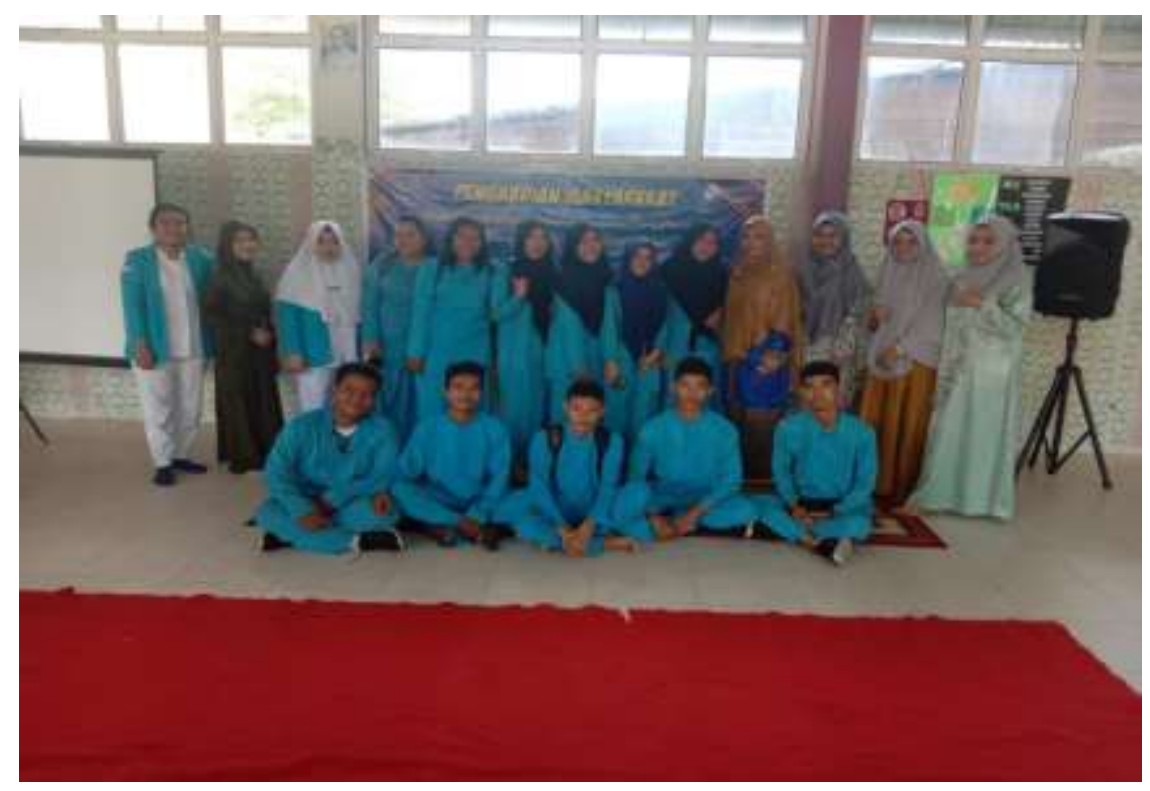

Gambar 6. Foto bersama dengan guru dan beberapa peserta

\section{KESIMPULAN}

Program pengabdian masyarakat kepada siswa berjalan dengan baik dan lancar. Siswa antusias dan memahami tentang seks bebas. Itu terlihat dari antusias mereka bertanya. Semua peserta pengabdian masyarakat berjumlah 32 Peserta yang terbagi didalam beberapa jurusan. Kegiatan dilaksanakan haru Jum'at pada tanggal 28 Februari 2020 di SMK Migas Teknologi Riau di JL. Srikandi, RT 04, RW 01 - Parit Indah, Kelurahan Simpang Tiga, Kecematan Bukit Raya, Kota Pekanbaru. Penyuluhan menggunakan infokus dan pemutaran viseo tentang seks bebas. Kegiatan melibatkan mahasiswa yang membantu dalam pelaksanaan kegiatan. Evaluasi dilakukan dengan metode tanya jawab secara langsung kepada siswa yang belum memahami materi penyuluhan.

\section{DAFTAR PUSTAKA}

Azinar, M. (2013). Perilaku Seksual Pranikah Berisiko Terhadap Kehamilan Tidak Diinginkan. KEMAS: Jurnal Kesehatan Masyarakat, 8(2), 153-160.

Dale, D. S., \& Dale, E. A. (2019). Psikologi Kebidanan. Pustaka Baru Press.

Hamka, M., Hos, H. J., \& Tawolo, M. A. (2015). Perilaku Seks Bebas di Kalangan Remaja. Phys. Rev. E, 2005, 24.

http://ridum.umanizales.edu.co:8080/jspui/bitstream/6789/377/4/Muñoz_Zapata_Adrian a_Patricia_Artículo_2011.pdf

Imron, D. (2012). Pendidikan Kesehatan Reproduksi Remaja. Ar Ruzz Media.

Kemenkes RI. (2014). Profil Kesehatan Indonesia 2014. Kementerian Kesehatan RI.

Marlina, H., Lapau, B., \& Ezalina. (2013). Perilaku Seksual Remaja SMA Negeri Se-Kota Pekanbaru Tahun 2012. Jurnal Kesehatan Komunitas, 2(2), 55-60. https://doi.org/10.25311/keskom.vol2.iss2.45

Maulana, H. D. . (2020). Penyuluhan Kesehatan. In Wikipedia Ensiklopedia bebas.

Radjagukguk, D. L., \& Sriwartini, Y. (2020). Peran Orangtua Menyikapi Pornografi Pada Remaja Melalui Komunikasi Efektif. Dinamisia : Jurnal Pengabdian Masyarakat, 4(2), 354-363.

Rokhmah, D. (2015). Pola Asuh dan Pembentukan Perilaku Seksual Berisiko Terhadap HIV /AIDS pada Waria. Jurnal Kesehatan Masyarakat, 4(1), 125-134.

Sarwono. (2013). Psikologi Remaja. Grafindo Persada. 
Setyadani, A. S. (2013). Perilaku Kesehatan Reproduksi Pada Anak Jalanan Dengan Seks Aktif Di Kota Semarang. Kemas - Jurnal Kesehatan Masyarakat, 9(1), 30-36. https://doi.org/10.15294/kemas.v9i1.2827

Yutifa, H., Dewi, A. P., \& Misrawati. (2015). Hubungan Paparan Pornografi Melalui Elektrinik Terhadap Perilaku Seksual Remaja. Jurnal JOM, 2(2). 